\title{
Managing Status: A Grounded Theory of Teacher Migration from Zimbabwe to South Africa
}

\author{
ZL Weda (Dr.) \\ Department of Educational Foundations, University of South Africa \\ wedazl@unisa.ac.za \\ EM Lemmer (Prof.) \\ Department of Educational Foundations, University of South Africa \\ lemmeem@unisa.ac.za
}

\section{Doi:10.5901/mjss.2014.v5n7p416}

\begin{abstract}
The migration of Zimbabwean teachers to South Africa has received little attention in terms of scholarly research. This paper focuses on factors which influence teacher migration from Zimbabwe to South Africa as they function in a grounded theory of teacher migration. Using a constructivist grounded theory approach; data were gathered from thirteen teacher migrants resident in South Africa for five years or less selected by theoretical sampling. Data gathering comprised written and oral life history accounts, which focused on the participants' main concerns during the migration process. Data analysis comprised initial, intermediate and advanced coding which led to the generation of a grounded theory on teacher migration revolving around the core category of Status. Levels of status were positioned on a continuum from Further diminished status, Diminished status, Ideal status to Ideal status surpassed. Migration, labelled as Escape due to its distinctive properties, was a demanding and last-resort process to maintain or achieve an ideal status understood in terms of three domains: working conditions, standard of living and social prestige that teacher professionals expect as normative. Prior to migration teachers adopted strategies to pull things together; when this process failed, teachers experienced things falling apart. In conclusion, the credibility and fit of the grounded theory is weighed within the framework of selected extant sociological and migration theories.
\end{abstract}

Keywords: grounded theory, teacher migration, Zimbabwe, South Africa, status

\section{Introduction}

Migration can be defined as the "more or less permanent movement of people across space" (Suarez-Orozco \& SuarezOrozco 2005, p.96). Large-scale migration is currently transforming the demographics of the population and the workforce of countries worldwide. The migration of teachers to the politically and economically dominant countries in the northern hemisphere was triggered by a skills shortage in these countries which began in the late 1980s and which could be attributed to their relatively large ageing population that can no longer adequately meet its own demands for labour (Campbell 2007). At the same time, the teaching profession suffered a loss of prestige and this resulted in a concomitant reduction in school leavers wanting to enter the teaching profession (McGregor 2006).

Large-scale teacher migration is a devastating problem faced by Zimbabwe. Accurate Zimbabwe teacher migration statistics are hard to come by because no comprehensive records have been kept and because of the sometimes clandestine nature of the migration. In spite of this, it is clear that the outflow of teachers from the country is considerable. Campbell (2007) estimates that Zimbabwe lost $75 \%$ of its teacher corps in the period 2000 to 2009 , not only to the United Kingdom, but also to neighbouring South Africa. Teacher migration has exacted a heavy toll within the country, leading to a skills drain in the education system and resulting in a number of school closures due to acute teacher shortages. Brown (2008, p.286) confirms this exodus of teachers with the comment that Zimbabwe is a "teacher labour-exporter par excellence of the current period". Studies of teacher migration from Zimbabwe are few and most recent migration studies deal mainly with the movement of medical personnel (Dovlo 2003) or migration at a macro level (Millers, Ouchs \& Mulvaney 2008; Pasura 2006; Manik 2009). To address the gap, this paper reports on a grounded theory study that explored factors that influenced teacher migration from Zimbabwe to South Africa. 


\section{Theoretical Framework}

The study of migration is deeply fragmented into competing disciplines and lacks a single unifying paradigm (Brettell 2008). Even wider is the divide between the social scientists that take a macro approach and examine migration within the context of policies, market forces and other large socio-economic units and those who adopt a micro approach and use the individual migrant or the migrant's family as the unit of the study (Brettell \& Hollifield 2008). This paper draws on selected macro, meso and micro theories to provide a theoretical framework of migration in general and teacher migration in particular.

Theoretical stances on the phenomenon of globalisation fall into the category of macro theories and provide both a cause of, and a context for migration. Globalisation has been variously defined and definitions usually concentrate on the economic impact (Oyejide 2002), particularly on the interdependence of global market economies (Brown 2008); however, cultural and technological aspects of globalisation cannot be ignored. This paper adopts a holistic definition of globalisation as both a process and the results of the integration of national economies and cultures, governance and technology in a global network through the reduction of time and space by the use of technology. Globalisation is usually placed within two contending discourses: the dominant neo-liberal discourse and the critical discourse (Shivji 2002). The philosophy of the dominant discourse is neo-liberal, based on the belief of a free market where market forces are allowed to reign unfettered by government interventions (Mohammed 2004). The critical discourse on globalisation is not homogeneous, but it is a loose amalgamation of thoughts whose unifying element is an emphasis on the extreme polarisation, inequalities and inequities that globalisation has caused and continues to cause. It highlights the destruction of livelihoods and the ecosystem, and the increasing income inequality between nations and individuals created by globalisation (Shivji 2002).

Globalisation functions as both the trigger and the facilitator of labour migration. Suarez-Orozco and SuarezOrozco (2005) propose the following ways in which globalisation interacts with migration. Firstly, labour tends to follow transnational capital flows, which are a major characteristic of globalisation, and thus stimulate migration. Secondly, globalisation affects the development of economies differently, producing success stories in some and disasters in others; and thus, creating conditions for migration by accentuating push and pull conditions which give impetus to migration. Thirdly, ongoing developments in information and communication technology and the ease of mass transportation stimulates migration by encouraging new cultural expectations, tastes, consumptions and practices - with satisfaction is usually only found elsewhere - and by availing people with a variety of transportation options. Finally, deeply globalised countries have built their economies around the assumption of the availability of the "foreign" worker, who is willing to do dull, dirty and dangerous work. Consequently, the business and other sectors in these countries encourage incentives and recruitment drives to obtain labour usually at the lowest cost possible.

Another comprehensive explanation of migration based on macro theory is proffered by, the push and pull factor theory. This theory broadens Suarez-Orozco and Suarez-Orozco's (2005) arguments to extend beyond the economic as primary dimension to include social conditions responsible for worker migration. Push factors refer to multi-dimensional hostile conditions in source countries that compel professional and skilled workers to emigrate and seek employment in other countries (Dovlo 2003). In addition to economic conditions, push factors include crime and conflict, political repression, excessive bureaucratic control, poor educational and career opportunities, technological underdevelopment and limited scope for self-advancement. Conversely, pull factors are the attractive socio-economic conditions in receiving countries that draw professionals. The out-migration of labour is subject to the disparities between sending and receiving countries in living conditions and employment opportunities (El-Khawas 2004). Dovlo (2003) goes further and describes the disparities that exist between the sending and receiving countries through various gradients: the income gradient, job satisfaction gradient, organisational environment and career opportunity gradient, governance gradient, protection and risk gradient and the social security and benefits gradients. Thus, Dovlo (2003) explains the flow of skills from one country to another or one region to another through disparities in these indices. A critique of the push and pull factor theory recognises the ongoing existence of migration gradients between countries, however, migration is not always the consequence. Thus, the influence of push and pull factors is useful, but insufficient to explain migration (Martin \& Taylor 2001).

The historic structural approach, which rests on neo-Marxist theory or world systems theory is yet another macro approach to migration. According to this approach the world economic system is capitalist and is characterised by an unfair division of labour that produces unequal exchange relations between different geographical regions (Wallerstein 1974). The world economic system is divided into three main geographical areas: core, semi-periphery and periphery. The core is comprised of economically and culturally dominant industrialised countries that buy raw materials from the countries constituting the semi-periphery and the periphery at low prices and then sells back the finished products to the 
same countries of the periphery and semi-periphery at higher prices (Mooney \& Evans 2007). The semi-periphery is a group of countries that are exploited by the core, but in turn exploits the countries of the periphery in the same way that it is exploited by the core. Migration is induced by the penetration of capital and investment into the periphery; these investments dislocate peripheral communities and spark international migration towards the core (Harzig, Hoerder \& Gabbaccia 2009; Ogbu 2004). The unequal terms of trade between the core and the periphery create the necessary inducement for people from the periphery to migrate towards the core in order to improve the quality of their lives.

Further insight into migration is engendered by transnationalism, a meso-level theory, which points out the important ongoing link that migrants maintain with their homeland. Migrants are not merely uprooted from their source country and permanently moored in the new state; instead they may move to and fro across geographical borders, cultures and social systems (Brettell 2008). Thus, migration includes a process whereby migrants maintain, build and reinforce multiple linkages with their country of origin, linking the source and destination country (Heisler 2008).

Another meso-level theory, the ethnic enclave theory, interrogates migrant behaviour with respect to the way that migrants affect the job market in the host country. Immigrants congregate in spatial concentrations in the host country creating an ethnic enclave economy, characterised by a clustered network of businesses owned by group members. The ethnic enclave economy offers the new immigrant a haven for language learning, on-the-job training and social mobility and is thus an alternative to the formal labour market (Heisler 2008). Initially these ethnic businesses are there to serve co-ethnics, but it may expand and extend services to the whole community.

On the micro level the family economy approach to migration uses the family as the unit of analysis in the study of migration (Brettell 2008). Its main contribution over macro and meso theories is its use of non-measurable factors, such as the emotional and spiritual, in the analysis of the migration decision of individuals (Harzig et al., 2009). The family economy theory also examines the income generation capacity of the family and its income allocation strategies. Accordingly, families send members abroad in anticipation of remittances that could boost the family's income. This is both a diversification strategy and a means of guarding against losses incurred by member migration (Harzig et al., 2009).

\section{Method}

The grounded theory design is defined as a systematic qualitative research procedure that is used to build a theory to explain a process, an action or an interaction, which is most useful when extant theories fail to adequately explain the phenomenon under study (Ellis \& Levy 2009). In the light of gaps that exist in research about teacher migration, a grounded theory design was adopted because of its usefulness in generating an explanatory theory that grows out of the data. Grounded theory discourse has followed a complex historical trajectory which can be traced from its origins in the seminal work of Glaser and Strauss (1967); the methodological split between the first authors (Glaser 1992; Strauss \& Corbin 1990); and the recent strand of constructivist grounded theory (Charmaz 2006; 2010; 2011). This study is placed within the ambit of constructivist grounded theory, which rejects the earlier assumptions of grounded theorists of the possibility of an objective and authoritative observer, the existence of an external and objective reality and its treatment of data without acknowledging the participation and standpoint of the researcher in shaping the data (Charmaz 2011). As co-authors, we understand grounded theory methods as a set of flexible analytical guidelines that encourage researchers to remain close to their studied world and to develop an integrated set of theoretical concepts, which synthesize and interpret as well as indicate processual relationships (Charmaz 2010). We have assumed an interpretive stance, whereby the ensuing analysis of migrant teachers' experiences constitutes a portrayal of reality, not an exact picture.

The sample for the study comprised thirteen qualified teachers (six women; seven men), migrants from Zimbabwe who have been continuously residing in South Africa for a period of one to five years. After the first participant who met these criteria was identified, subsequent participants were selected by theoretical sampling. Theoretical sampling, typical of the grounded theory, aims to expand and check the properties of a tentative category and does not seek to achieve demographic representation of those chosen (Charmaz 2011). In theoretical sampling, the researcher concurrently collects codes and analyses data and then decides what to collect next and where to find participants in order to develop a theory as it emerges (Glaser \& Strauss 1967). Data were gathered through a two-stage process. Firstly, participants were given the choice of relating their migration history in a written or an oral narrative, the latter occurred via semistructured interviews. The second stage comprised follow-up interviews for further exploration of the emerging theory through clarification and expansion of incidents with a view to saturation of categories. The chief researcher (Weda 2012) conducted interviews at a time and venue preferred by participants, using English, IsiNdebele or Shona for communication. Interviews were digitally recorded, transcribed and translated into English where necessary. Participants and researcher co-signed a consent form, which detailed the purpose of the study, the protection afforded participants by 
keeping identities confidential and the opportunity to obtain results.

Data analysis occurred simultaneously with data collection (Charmaz 2010) and proceeded through three coding stages: the initial, intermediate and advanced. In the initial stage, line-by-line coding was used to fracture the data and name the processes and actions in each line of the interview transcript or written account (Holton 2010). During the intermediate stage, the data was restructured into categories identified in the data with the view to identifying the core category emerging from the data, the sub-categories and the properties (characteristics) of categories. In the advanced coding stage, the grounded theory emerged through theoretical integration, whereby the core category was integrated with other sub-categories and processes by establishing theoretical links between them. Memo writing (that is; the writing of short detailed insights and comments on incidents and linkages) accompanied the entire analytical process (Charmaz 2010). Charmaz's (2006) criteria for evaluation of grounded theory studies were adopted as a guide to maintain trustworthiness and the value of research findings: credibility, originality, resonance and usefulness as seen in the section entitled, "Discussion".

The findings are presented through an illustrative model (Figure 1) (Cresswell 2008) and an exposition of the grounded theory using a narrative storyline, illustrated and substantiated by rich data (Birks \& Mills 2011).

\section{Findings}

Figure 1 presents an illustrative model of the grounded theory generated by the study. This is followed by the exposition of the model thus developed, giving attention to all the terms used.

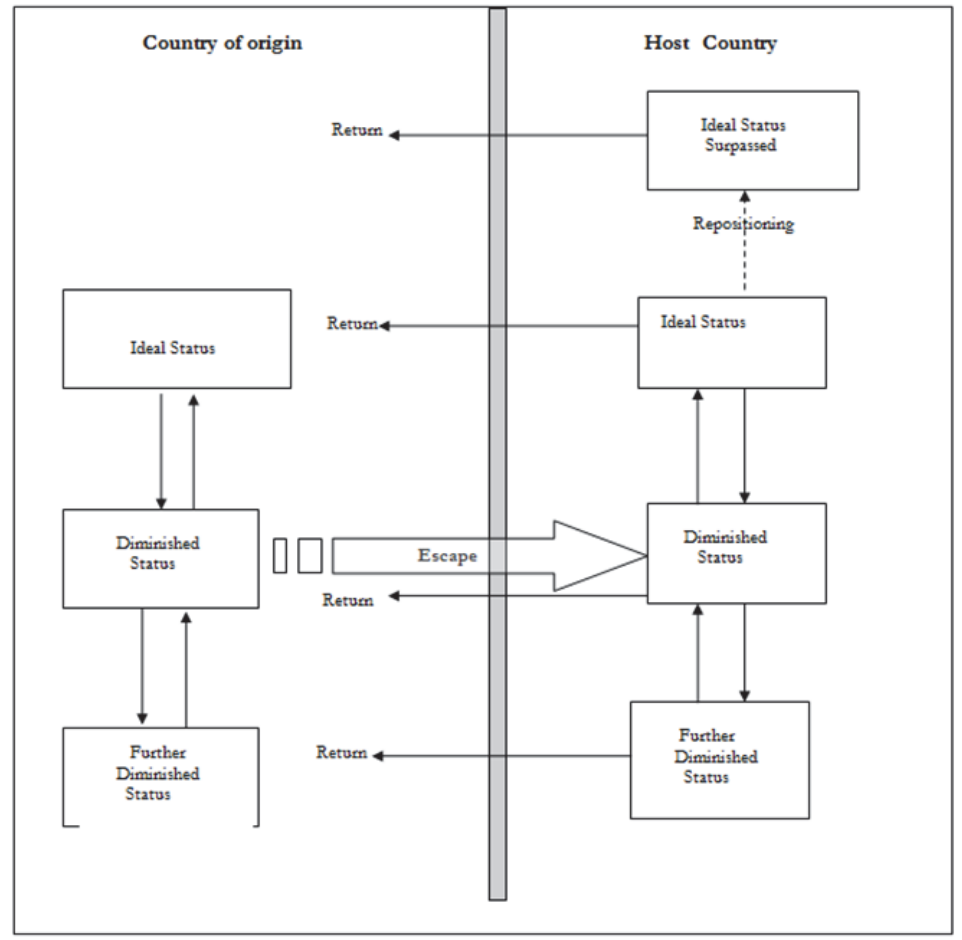

Figure 1: Illustrative model of the grounded theory

The core category of the grounded theory is Status which functions on four levels: Ideal status surpassed, Ideal status, Diminished status and Further diminished status. Pre- and post-migration threats to the Ideal status are indicated by the process: Things fall apart (vertical arrow downwards); pre- and post-migration efforts to defend Ideal status are indicated by the process: Pulling things together (vertical arrow upwards). Escape (migration) is indicated by the horizontal arrow from country of origin to host country. Return is indicated by the horizontal arrows from host country to country of origin. Repositioning is indicated by the vertical broken arrow between Ideal status and Ideal status surpassed. 


\subsection{Exposition of the grounded theory: core category and sub-categories}

The primary function of the core category is to integrate the theory and render it dense and saturated (Holton 2010). The core category that represents the main concern of all participants, irrespective of individual differences, is Status. Four sub-categories representing the different levels in which Status may function were identified as: Ideal status surpassed, Ideal status, Diminished status and Further diminished status. The sub-categories were positioned on a continuum stretching from the most negative pole, Further diminished status, to the most positive pole, Ideal Status Surpassed.

Ideal status was the mental construct shared by all participants which was shaped by their lived experience as teachers in contemporary Zimbabwean society as well as by their perceptions of the status enjoyed by teachers in other education systems, including South Africa. Teacher migrants endeavoured to achieve Ideal status, which was constituted by three interconnected domains: working conditions, standard of living and social prestige.

Prior to migration, participant expectations of what could be considered normative for these domains had been thwarted and, thus, participants functioned at either the level of Diminished status or Further diminished status. As qualified and experienced professionals, the participants had been disenchanted by their working conditions. Hopes of an acceptable salary, opportunities for career progression and professional development, adequate housing, transport in the case of rural schools, teaching resources and classroom conditions had been disappointed in an education system under strain due to poor economic conditions, exacerbated by political uncertainty. Salaries were meagre, as confirmed by a participant who stated: "At the end of the day we were getting not peanuts but nutshells. Eventually we ended up sort of rendering a [free] service to the state." Consequently, prospects of raising one's standard of living were miserable, corroborated by the following statement by a participant: "I was convinced I would never meet my aspirations within the country. In education as profession, I wanted to advance to a PhD, buy a house and a car."

Further, principles of academic freedom were threatened in a volatile political climate in which teachers, as part of the professional elite, were suspected of promoting opposition politics in the classroom by the ruling party. A participant described political surveillance of his teaching: "People from the C.I.D. [state security organisation] went to schools to listen and observe teachers and we no longer had freedom in our schools."

Poor working conditions put the achievement of social indicators of an acceptable living standard such as property ownership, household goods, a car, the enrolment of children in good schools or access to further education, beyond reach. The standard of living was further lowered by deteriorating services in residential areas: poor or erratic delivery of health services, electricity, running water, and sewage and refuse collection. A participant asserts: "You know when you have been away for some time you see these things even more clearly, rubbish at the corners, sewage water flowing, no electricity and...the rats in our houses!"

A living standard inferior to what participants considered their due, reduced their social standing in the community and rendered them unable to fulfil the social roles, duties and obligations associated with teachers as a status group, such as performance of funeral duties and financial support of parents and extended family. This inability to perform their social roles, duties and obligations wore down family and community respect. The erosion of Ideal status through the cumulative demise in the three domains and their slide into Diminished or Further diminished status knitted the participants' narratives together.

\subsection{Exposition of grounded theory: processes}

Prior to migration, participants strove to achieve the Ideal status by adopting one or more strategy for status recovery in a process termed pulling things together. Career related strategies included improving educational qualifications in order to position oneself for promotion; applying for promotion; agreeing to act in certain capacities for little or no remuneration to accelerate career progression; frequently changing jobs without improving post level to secure other perceived benefits, such as employment in a more prestigious private school which included benefits, such as, free tuition for offspring, housing and transport; and bargaining and/or striking for higher salaries. Unconventional status recovery strategies included income generation projects unrelated to the profession (for example, small commercial enterprises, cross-border trading, forming saving and shopping clubs) and unauthorised incentives such as informal payoffs from parents with the proviso that they would not engage in disruptive teacher strikes.

Endeavours to achieve Ideal status became crucial when these status recovery strategies failed and participants entered a new process labelled, things fall apart, that is, the rapid downward spiral of personal circumstances. This process was developed from an in vivo code encapsulated in a participant's actual words: "Things were falling apart." Things fall apart captured the individual's inability to exercise control over his/her declining working conditions and living conditions and crumbling social prestige. At this point, participants began to turn to migration as a final resort to recover 
status by seeking a teaching position in a foreign education system where it was believed Ideal status could be reached. In this sense, migration differed qualitatively from the status recovery strategies which fell under the process, pulling things together. Migration came at a far higher price and was only undertaken when accumulated problems reached a critical tipping point.

According to the grounded theory, migration is labelled Escape to convey a richly tuned process which comprised considerable risk, physical uprooting and an emotional rupture with the homeland, family and friends. The gamut of intense and often conflicting emotions which accompanied migration ranged from relief, inspired by escape from a distressing situation, to anxiety about the future and self-doubt about the efficacy of migration as a solution to personal and professional problems. A participant summed it up in the opening sentence of her narrative: "It is never easy to leave your home country for another."

Escape thus captured the distinctions of the lived experience more accurately than the blander term, migration. This choice is substantiated by participant stories. Some teachers had to relocate themselves and their nuclear family; others were compelled to leave their children and spouse behind, in anticipation of a later reunion, and make the move alone. The journey was made with or without legal documentation, and with or without securing a teaching job in the host country. Financial help was sought from family at home or from expatriates who had already migrated to South Africa or abroad.

However, the nature of Escape did not preclude planning. Most participants began with a meeting of the nuclear family to discuss the sequence of the move, disposal of property, plans to minimise disruption of children's education, sources of financial help and of accommodation in South Africa and the securing of legal papers. "We sat down with my wife and decided things cannot go on this way forever," explained a participant.

Staggered departures provided a safety net in case things did not go well for the migrant. The urgency of Escape was demonstrated by the way some participants abandoned their teaching posts without formal resignation. $\mathrm{C} 1$ said: "There was no pension to claim, the employer could not pay us (salaries) let alone give us pension. I just did not have the time to waste on bureaucratic issues [of resigning formally]." Yet the drive to escape distress and ultimately improve Status often required a precipitating event, a "last straw". Escape also required endurance, since, for many participants, the journey to South Africa was arduous. Most participants used the cheapest means of available transport to reach their destination, as demonstrated by this anecdote: "I didn't have enough money to see me to South Africa. I used one of these so-called chicken buses and I was surprised it obtained to Jo'burg without a problem!" A "chicken bus" is a colloquialism for the uncomfortable and often mechanically faulty busses used by the poor in Zimbabwe. Only one participant out of the thirteen, a woman who migrated to re-unite with her husband, who had preceded her, flew with her children form Harare to Johannesburg.

Escape was the preferred option shared by the participants to achieve Ideal status in the face of Diminished status in the home country. However, the achievement of Ideal status is not an automatic outcome of Escape and the participants faced the risk of further setbacks if their post-migration situation failed to improve. In this event some ended up in a position similar or worse than the one from which they escaped, usually due to the failure to secure a teaching position that could have sustained the migrant financially. This situation was exacerbated, inter alia, by difficulties in securing work and residence permits, lack of appropriate qualifications required by the South African education system and the lack of affordable accommodation. Three participants slipped into the Further diminished status category and had to resort to blue collar employment as waiters, domestic workers or security guards. A former language teacher of English and Portuguese described her misfortune: "At the moment I am struggling as a waitress. In fact I don't get a basic salary. I earn from a commission and tips from the customers. This means if I don't go to work, then I don't have money."

This notwithstanding, these participants may recover from their diminished status by again employing recovery strategies such as those included in the Pulling things together category. Several teachers achieved the Ideal status category and engaged in a new process, termed Repositioning to enhance their status further and achieve the most positive pole of the status continuum, Ideal status surpassed. However, only one participant judged himself as having achieved this status level.

The process of Return refers to permanent relocation of the participant, back in the country of origin. Return emerged at the outset of data gathering and was a refrain throughout all narratives. However, opinions concerning return were not uniform, ranging from wishful thinking to outright rejection of return prospects. Conflicting sentiments are detected in these quotations: "Home is where we belong. And home, we need to get back home." This is contrasted with, "I would return if the political repression would be gone and the economy would be back on its feet."

Return was a process viewed as gravely as the initial migration from the country of origin. Sober consideration of Return implies that the migrant must revisit and weigh the option of, once again undergoing both the practical upheaval and the emotional turbulence involved in the initial migration process. Further, a different set of motivators operated 
according to the Status levels achieved by migrants. Participants with Diminished status could be expected to consider Return the most strongly; however, they are also deterred from this option by loss of face in the home country and the prospect of rebuilding their lives from an even weaker position than before. At the other pole of the Status continuum, the lone participant, judged to have surpassed Ideal status, felt that success militated powerfully against Return: "I would be lying to say I intend to go back. I am quite comfortable...my family is here I am settled. Eh, at the moment I'm seeing South Africa as my permanent home."

The following section deals with a discussion of the grounded theory's possible contribution to a deeper understanding of factors driving teacher migration. Both the literature referred to earlier (theoretical frameworks) and additional works have been consulted to interrogate the research results in the context of extant sociological and migration theory.

\section{Discussion}

The foremost question posed concerns the credibility of the use of Status as core category in the grounded theory of teacher migration. Although participants functioned at different status levels on the continuum, the central concern of all the participants was the endeavour to attain a minimum Status level. Status thus effectively incorporated all initial categories identified (Ideal status, Ideal status surpassed, Diminished status and Further diminished status) and, as the theory emerged from the data, these became sub-categories. Processes (Things fall apart, Pulling things together, Escape, Repositioning and Return) appropriately linked sub-categories to the core category. The three domains in which Ideal status was conceptualised, that is, working conditions, standard of living and social prestige, were useful in determining individual evaluations of Status.

Thus, the core category, Status, can be fruitfully employed as an indicator of teacher job satisfaction and the extent to which a teacher may consider migration. This is potentially useful to educational planners in their consideration of national teacher retention and erosion. Planners and policymakers who wish to retain teacher expertise should thus address teacher concerns about Status. If they neglect to do so, it will become increasingly difficult to retain teachers either in the profession or in a national education system. Thus, Status is a key aspect of teacher deployment policies and it directly affects the quality of education within a country. Status is also useful in understanding how to attract migrant teachers back to the education system of the country of origin. Any consideration of Return on the part of migrants hinges, in complex ways, on Status. For example, the study indicated that teachers who have attained or surpassed Ideal status will resist return if such a move jeopardises Status. Ironically, however, even in the case of Diminished status, a teacher may opt to remain, despite uncertain conditions, in the host country to avoid losing esteem or further material loss through repatriation. Therefore, we judged that Status as a core category, has added to an understanding of teacher migrant decision-making, both in the home and host country.

In addition, the question can be posed as to the effectiveness of migration in the achievement of Ideal status. The findings indicated that the longer the time spent in the host country, the greater the efficacy of migration as a means to alter Status positively. The nine participants who had managed to improve Status had resided in South Africa for three or more years. Only one of these nine participants had surpassed Ideal status and had been continuously employed as a teacher for four years, which had facilitated his Repositioning. He was also one of the few participants who had obtained legal documentation prior to migration and had secured a job before arrival. The remaining four participants functioned at levels of Diminished status. Time is therefore a key factor in effectiveness of migration and this finding is significant for any teacher considering migration. Moreover, the findings also indicate that a hasty 'escape' without legal documentation and a teaching contract, does not bode well for the migrant.

Having established that the core category, Status, had reasonable fit within the grounded theory, our discussion turns to status as it functions within sociological theories. Weber (1946) is widely credited for introducing social status as the location of a person (or group) in the social strata based on the amount of social prestige or respect which a person is accorded by others. Ritzer and Ryan (2011) elucidate Weber's definition by linking social status to location in the social hierarchy of honour and prestige. Pampel (2007), also with reference to Weber, regards social status as based more on social evaluation than on economic position; thus, in capitalist societies money means less than the lifestyle that it supports. This corroborates, to some extent, the particular meaning lent to Status by the grounded theory: standard of living and social prestige were dependent on teacher salaries, but in reality prestige, in terms of community respect and the ability to fulfil social obligations, was more important than salary alone. This relates to Merton's (1957) role-set theory which posits that a person does not assume one role and one status, but a single status usually has a role-set attached to it. Based on Merton's role-set theory, Applerouth and Edles (2008) explain social status as a position in a social system which has a distinctive array of designated rights and obligations. Kendall (2003) adds that a person (or group) entertains 
certain expectations about their rights, duties and privileges linked to their status.

These dimensions of status, contained in the sociological theory mentioned above, were echoed in the grounded theory put forward in this study: participants had expectations about their social position and accompanying duties that they felt they should perform as a function of that status. Thus, participants formed a status group linked to a specific lifestyle and consumption patterns expected of its members (Adam \& Sydie 2002). From a Weberian perspective, high status group members distinguish themselves from society by means of a distinctive and highly respected lifestyle marked by entitlement to certain social goods, services and opportunities (Pampel 2007). According to these findings, in Zimbabwean society, teachers formed a high status group with concomitant rights, privileges and expectations. The efforts of the participants to recover or defend Status were grouped around Pulling Things Together. However, as the onslaught on their position as a status group intensified, status group identity and uniqueness was eroded, self-esteem suffered and migration (Escape) became the preferred action.

This brings the discussion to the location of the grounded theory amidst the set of extant migration theories. As mentioned before, migration has been variously defined; however, definitions all include the notion of a dramatic uprooting of individuals, movement across space and eventual settlement in a new location and society (Suarez-Orozco \& Suarez-Orozco 2005; Harzig et al 2009). These aspects were readily observed in the participants' narratives. Further, transnational theories of migration, such as that proposed by Brettel (2008), challenged the idea of migration as a cutand-dry movement of person(s) from one place to another. The suggestion is that migration also involves simultaneous engagement in the source and host country whereby migrants maintain multiple cross-border relations-- familial, socioeconomic, political and religious (Sorensen, van Hear \& Engberg-Pedersen 2002). Similarly, in this study, all the participants engaged in transnational activities: they are in constant contact with their relatives and friends in the home country and are avid followers of Zimbabwean news. Their lives are split between the two countries; they frequently travelled back and forth to check on family members, to invest in or disinvest from interests they have in Zimbabwe. Although the migrants did not themselves articulate the transnational definition per se, it is reflected in their lived experiences.

Further, earlier comments about globalisation, as both the cause and context of migration, were validated by the migration experience contained in the grounded theory. Among others, globalisation propels migration by differentially benefitting the globalising countries, creating winners in some and losers in others. This creates or enhances the migration gradient between the successes and failures (Shivji 2002). South Africa is a more globalised economy than Zimbabwe, judging from the relationship of the economies of the two countries to the global capitalist economy and their ranking in global economic competitiveness (World Economic Forum 2011, p.15). To some extent then, globalisation is responsible for the differences in the economies of Zimbabwe and South Africa and, therefore, in the working and living standards of teachers in the two countries and has created a migration gradient between the two countries which favours migration to South Africa.

In addition, propositions of the world systems theory, which identifies core, semi-periphery and periphery countries, are partially validated by the migration experiences of participants. Unfavourable conditions in the periphery, increases the attractiveness of the core (Harzig et al 2009). Zimbabwe is easily classified as part of the periphery due to its weak economy (ZIMSAT and IOM 2010); South Africa, an emerging economy, could be located in the semi-periphery (World Economic Forum 2011). Accepting this classification implies that teachers migrating from Zimbabwe to South Africa are moving from the periphery to the semi-periphery. Further movement is also indicated by the wold systems theory: Zimbabwean migrant teachers move in to replace skilled South African counterparts who have migrated to the developed core, especially the UK (Miller et al 2008). From a macro perspective, this theoretical standpoint offers an almost plausible explanation of teacher migration: teachers are drawn towards the core by the higher standard of living available as one approaches the core; the movement is from the periphery to the semi-periphery and from the semi-periphery to the core. However, this theory suffers the limitation of all macro theories in that it portrays the individual as a passive participant to macro-economic forces; it fails to explain what motivates individuals and why some move, while others remain within the same country. Neither does it explain what personal issues are taken into account in the movement decision (Brettel 2008).

The push and pull factor theory does not propose anything radically different from the world systems approach, since it posits that poor economies push away the workers, whilst the higher wages and better standards of living in the more industrialised regions pull them in (Harzig et al 2009). If migration is thus perceived purely as an economic phenomenon (Nkamleu \& Fox 2006), then the movement of workers from a weak economy to a stronger one makes sense because they are going to make more money in the stronger economy. Indeed, participants in this study clearly moved from a depressed economy, poor living standards and political insecurity to a situation where all these conditions were considerably better. So it could be argued that participants did an informal cost-benefit analysis and decided that 
they would gain more by migrating. Hence, the push and pull theory explains to a great extent the teachers' motivation for migration at individual level.

However, the grounded theory demonstrated that there was more involved in the decision to migrate than merely economic push and pull factors. As already explained, participants migrated to improve status which is comprised of a complex interplay of factors, including working conditions, standard of living and social prestige. Their concerns were wider than the narrower concerns of the push and pull theory. In this regard, migration networks become an important facilitating factor to add to this discussion. Migration networks include everything that enables people to learn about opportunities abroad and take advantage of them (Martin \& Taylor 2001) and this explains why some people migrate while other in the same conditions do not. All of the participants in this study obtained some assistance from migration networks in Zimbabwe, South Africa and further abroad in the form of cash, information and moral support. Moreover, long-term political and socio-economic relations between sending and destination countries have been proposed as a facilitating factor in international migration (Papademetriou, 2003). In this case, Zimbabwe and South Africa share lengthy political and socio-economic relations as well as a long and dynamic migration history (Zuberi \& Sibanda 2005). These ties were powerful facilitating factors which made the participants' migration experiences less daunting, as it was a journey along well-beaten paths which had previously been shared by many of their compatriots, albeit in different contexts at different points in time.

On a micro level, the family economy theory permits the inclusion of non-measurable factors such as emotional and spiritual factors in the analysis of migration decisions of individuals (Harzig et al 2009, p.75). Among others, this theory highlights the role of the migrant who precedes his/her family to the host country and maintains the family left behind through remittances that boost the family's income and act as a buffer against further losses in the distressing circumstances back home. Thus, migration is a type of income diversification (Harzig et al 2009). The family economy theory was partly borne out by the grounded theory contained in this paper. The migration process labelled, Escape, indicated that generally the migrant's family was consulted in the decision to migrate and migration was seen as a way to buffer the family income which was under strain due to teachers' poor working conditions. As an income diversification strategy, the participants who left their spouses and children behind sent funds home to care for dependents. However, the family economy theory resonates primarily with the emotional aspects of migration embedded in the participants' narratives: participants were both driven to migration to better their lot and torn between migration and family loyalties. This emotional conflict was exemplified by the energy and the ingenuity ploughed into a wide range of prior migration efforts (Pulling things together) to improve status and to avoid migration as well as by the recurrence of the theme of Return in participants' accounts of post-migration life in South Africa.

\section{Conclusion}

The grounded theory proposed in this paper has endeavoured to add insight to the phenomenon of teacher migration by exploring the experiences of Zimbabwean teachers who migrated to South African as a means of managing status. Diminished status calls for several pre-migration strategies to improve deteriorating working conditions, living standard and social prestige. When these strategies fail and personal circumstances spiral downward, migration becomes an option. However, migration is a highly demanding and risky process. The efficacy of migration as a means to recover or improve status is dependent on length of time in the host country and other enabling conditions. Return of migrants is a theme which penetrates all migrant stories, but appears to be an elusive option imbued with its own risks.

\section{References}

Adams, B.N., \& Sydie, R.A. (2002) Classical sociological theory. London: Pine Forge Press.

Applerouth, S., \& Edles, L.D. (2008) Classical and contemporary sociological theory: Text and readings. Los Angeles: Pine Forge Press. Birks, M., \& Mills, J. (2011) Grounded theory: A practical guide. London: Sage.

Brettell, C.B., \& Hollifield, J.F. (eds.). (2008) Migration Theory: Talking across disciplines. New York: Routledge.

Brown, B. (2008) Teacher migration impact: a review of quality education provision and teacher training in higher education in southern Africa. SAJHE, 22 (2): 282-301.

Campbell, E.K. (2007) Brain drain potential in Botswana. International Migration, 45 (5):115-145.

Charmaz, K. (2006) Constructing grounded theory: a practical guide through qualitative analysis. London: SAGE.

Charmaz, K. (2010) Grounded theory: objectivist and constructivist methods. In W. Luttrell (Ed.). Qualitative educational research: readings in reflexive methodology and transformative practice (pp.183-207). New York: Routledge.

Charmaz, K. (2011) A constructivist grounded theory analysis of losing and regaining a valued self. In F.J. Wert, C. Charmaz, L.M. McMullen, R. Josselson, R. Anderson \& E. McSpadden (Eds.). Five ways of doing qualitative analysis (pp.165-204). New York: 
The Guildford Press.

Corbin, J., \& Strauss, A. (1990) Grounded theory research: procedure, canons and evaluative criteria. Thousand Oaks: Sage.

Creswell, J.W. (2008) Educational research: Planning, conducting, and evaluating quantitative and qualitative research. (2nd edition) Upper Saddle River: Pearson.

Dovlo, D. (2003) The brain drain and retention of health professionals in Africa. Paper presented at: Improving tertiary education in SubSaharan Africa: Things that Work. Retrieved October 28, 2009, from www.medact.org/content/health/documents/brain_drain/Dovlo\%20-\%20brain\%20drain\%20and\%20retention.pdf.

El-Khawas, M.A. (2004) Brain drain: putting Africa between a rock and a hard place. Mediterranean Quarterly, Fall: 38-56.

Ellis, T.J., \& Levy, Y. (2009) Towards a guide for novice researchers on research methodology: review and proposed methods. Issues Informing Science and Information Technology, 6 (20): 323-337.

Glaser, B. (1992). Basics of grounded theory analysis. Mill Valley: Sociology Press.

Glaser, B., \& Strauss, A. 1967. The discovery of grounded theory. Chicago: Aldine.

Harzig, C., Hoerder, D., \& Gabaccia, D. (2009) What is migration history? Cambridge: Polity.

Heisler, B.S. (2008) The sociology of immigration: from assimilation to segmented assimilation from American experience to global arena. In C.B. Brettell \& J.F. Hollifield (Eds). Migration theory: Talking across disciplines. (pp.1-30). New York: Routledge.

Holton, J.A. (2010) The coding process and its challenges. The Grounded Theory Review, 9(1): 265- 289.

Kendall, D.E. (2003) Sociology in our times: the essentials. (3rd edition). Belmont: Wadsworth Publishing.

Manik, S. (2009) Understanding the exit of teachers from South Africa: Determinants of transnational teacher migration. Perspectives in Education, 27 (3): 43-56.

Martin, P.L., \& Taylor, T.E. (2001) Managing migration: the role of economic policies. In A.R. Zolberg \& P.M. Benda (Eds.). Global migrant, global refugees: problems and solutions (pp.95-120). New York: Berghahn.

McGregor, J. (2006) Zimbabwean nurses and teachers negotiating work and family in Britain: Geographical Paper No.178. Reading: University of Reading.

Merton, R.K. (1957) The role-set: problems in sociological theory. The British Journal of Sociology. 8, (2): 106-120.

Miller, P.W., Ochs, K., \& Mulvaney, G. (2008) International teacher migration and the Commonwealth teacher recruitment protocol. European Education, 40(3):89-101.

Mohammed, S.B. (2004) The socio-cultural impact of globalization in Nigeria. In J.S. Odama, \& E.A. Aiyedun, (Eds.). Globalisation and Third World Economy: impact and challenges in the 21st century (pp.51-61). Lagos: Malthouse Press.

Mooney, A., \& Evans, B. (2007) Globalization: the key concepts. New York: Routledge.

Nkamleu, G.B., \& Fox, L. (2006) Taking stock of research on regional migration in Sub-Saharan Africa. Munich: Personal Repec Archive.

Ogbu, S.O. (2004) The democracy movement and globalisation: Nigeria in perspective. In J.S. Odama \& E.A. Aiyedun, (Eds.). Globalisation and Third World Economy: impact and challenges in the 21st century (pp.30-41). Lagos: Malthouse Press.

Oyejide, T.A. (2002) Globalisation and its economic impact: An African perspective. In E. Jansen, J. Mwapachu \& J. Semboja (Eds.). Local perspectives on globalisation: the African case (pp.15-28). Dar es Salaam: Mkuki na Nyota.

Pampel, F.C. (2007) Sociological lives and ideas: an introduction to classical theorists. New York: Worth Publishers.

Papademetriou, D.G. (2003) Managing rapid and deep change in the newest age in migration. In S. Spencer, (Ed.). The Politics of migration: managing opportunity, conflict and change (pp.39-59). Oxford: Blackwell Publishing.

Pasura, D.M. (2006) Mapping Exercise Zimbabwe. London: International Organisation for Migration.

Shivji, G. (2002) Globalisation and popular resistance. In E. Jansen, J. Mwapachu \& J. Semboja, (Eds.). Local perspectives on globalisation: the African case. (pp.101-118). Dar es Salaam: Mkuki Press.

Sorensen, N.N., Van Hear, N., \& Engberg-Pedersen, P. (2002) The migration-development nexus evidence and policy options: state of the art overview. Centre for Development Research Working Paper, no 2. Denmark: Centre for Development Research.

Suarez-Orozco, M., \& Suarez-Orozco, C. (2005) Globalisation: immigration and education: recent United States trends. In M.S. Sorondo, E. Malinvand, \& P. Lena (Eds.). Globalisation and education: proceedings of Joint Working Group (pp.94-126). Berlin:Walter de Gruyter.

Wallerstein, I. (1974) The modern world system: capitalist agriculture and the origins of the European World-economy in the sixteenth century. London: University of London Press.

Weber, M. (1946) Essays in sociology. New York: Oxford University Press.

Weda, Z.L. (2012) Factors influencing the migration of teachers from Zimbabwean to South Africa (Unpublished doctoral thesis). UNISA, Pretoria.

World Economic Forum. (2012) The Global Competitiveness Report: 2010-11. Available at http://www3.weforum.org/docs MEF_GlobalCompetitivenessReport_2010-11.pdf [accessed 26 August 2012]

ZIMSAT (Zimbabwe National Statistical Agency) and IOM (International Organisation for Migration). (2010) Migration in Zimbabwe: a country profile. Harare: ZIMSTAT and IOM.

Zuberi, T., \& Sibanda, A. (2005) Migration and employment. In T.Zuberi, A.Sibanda \& E.Udjo (Eds.). The demography of South Africa (pp. 266-296). New York: M.E. Sharpe. 